\title{
Synthesis and radical oxidation of steroidal 1-oxo-5a-alcohols
}

\author{
Vladimir A. Khripach, ${ }^{a}$ Vladimir N. Zhabinskii, ${ }^{\mathrm{a}, *}$ Galya P. Fando, ${ }^{\mathrm{a}}$ Natalya B. Khripach, ${ }^{\mathrm{a}}$ \\ and Bernd Schneider ${ }^{\mathrm{b}}$ \\ ${ }^{a}$ Institute of Bioorganic Chemistry, National Academy of Sciences of Belarus, Kuprevich str., \\ 5/2, 220141 Minsk, Belarus \\ ${ }^{b}$ Max-Planck-Institute for Chemical Ecology, Beutenberg Campus, Hans Knöll Str. 8, D-07745 \\ Jena, Germany \\ E-mail: khripach@iboch.bas-net.by
}

Dedicated to Professor Oleg Kulinkovich on the occasion of his $60^{\text {th }}$ birthday

\begin{abstract}
A new synthetic approach is described for the preparation of steroidal 1-oxo-5 $\alpha$-alcohols. A key step in the synthesis was the [2,3]sigmatropic rearrangement of allylic $3 \alpha$-selenide ensuring the introduction of the desired functional groups at C-1 and C-5. The radical oxidation of 1-oxo-5 $\alpha$ alcohol was shown to proceed with the formation of 5,10-seco steroid. Its structural assignment was based on NMR and CD spectroscopic studies.
\end{abstract}

Keywords: Seco steroids, radical oxidation, allylic selenide, [2,3]sigmatropic rearrangement

\section{Introduction}

A key step in the preparation of 5,10-seco steroids (which are characterized by enhanced backbone flexibility $)^{1,2}$ is a rupture of endocyclic bonds. Oxidative $\beta$-fragmentation of $5 \alpha$ alcohols by lead tetraacetate in the presence of iodine has been used repeatedly to synthesize such compounds. ${ }^{3}$ 


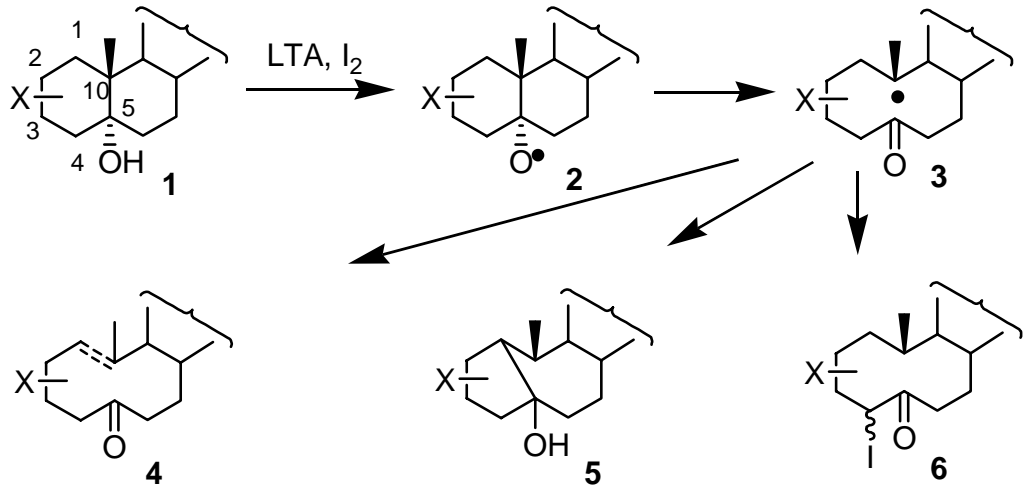

\section{Scheme 1}

The course of the reaction is rather complex (Scheme 1$)^{4-7}$ the intermediate formation of radical species $\mathbf{2}$ and $\mathbf{3}$ has been suggested to give ultimately a number of compounds like enones 4, cyclization products 5 and iodides $6 .{ }^{8}$ This limits the applicability of the reaction in a directed synthesis of corresponding seco steroids.

A similar reaction was used for the preparation of 13,14-seco steroids based on the radical oxidation of $14 \alpha$-alcohols. Basically, the obtained results were the same. ${ }^{9}$ However, there was an exception in the case of derivatives containing a keto group at C-17. Their oxidation proceeded smoothly, resulting in a good yield of iododiketones, which are convenient intermediates for further modifications. ${ }^{10}$ This approach was successfully used to prepare a number of androstane 13,14-seco steroids. ${ }^{11,12}$

The main idea of the present investigation, which aimed to develop new synthetic approaches to 5,10 -seco steroids, was to examine the influence of a carbonyl group at $\mathrm{C}-1$ (in $\beta$-position to hydroxyl group at $\mathrm{C}-5$ ) on the course of radical oxidation.

\section{Results and Discussion}

Synthesis of the required 1-oxo-5 $\alpha$-alcohol posed certain problems. In general, the functionalization at $\mathrm{C}-1$ in steroids remains a difficult challenge, which is associated first and foremost with the preparation of vitamin D metabolites. ${ }^{13}$ However, the experience accumulated in this field could not be applied in our case because of the necessity of a $5 \alpha$-hydroxy group. Using a method employed earlier to prepare a germacrane alcohol, allohedycaryol, solved the problem. $^{14}$

We started (Scheme 2) with the allylic alcohol 7 that has already been described in the literature. $^{15}$ Its treatment with o-nitrophenyl selenocyanate proceeded by inverting stereochemical configuration ${ }^{16}$ at $\mathrm{C}-3$ to give $\alpha$-derivative 8 . Oxidation of this allylic selenide with hydrogen peroxide triggered a [2,3]sigmatropic rearrangement ${ }^{17}$ that finally led to compound 9 which has a $\Delta^{2}-1 \alpha$-hydroxy functionality. What is remarkable for the rearrangement of such a specific system ${ }^{14}$ as that in AB-cycles of selenide $\mathbf{8}$ is the simultaneous $\alpha$-epoxidation of $\Delta^{5}$-double bond, probably as a result of the intermediate formation of arylperoxyseleninic acid derivative. $^{18}$ 

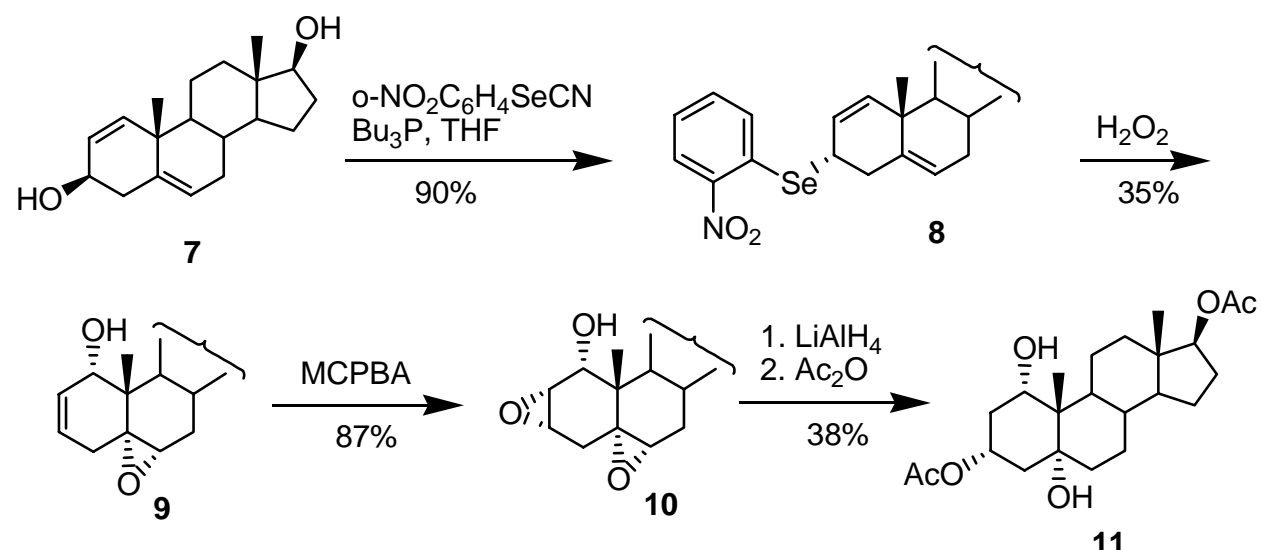

\section{Scheme 2}

Thus, the overall result of the above process was the functional group at $\mathrm{C}-1$ and providing the necessary prerequisites for proper functionalization at C-5. The stereochemistry of $\Delta^{2}$-bond epoxidation in 9 was synchronously controlled by both adjacent $\alpha$-hydroxyl group at $\mathrm{C}-1$ and attack of the reagent from the less hindered $\alpha$-side of the steroidal molecule. Hydride reduction of the diepoxide $\mathbf{1 0}$ gave a mixture of products, none of which could be separated at this stage. The problem was solved by acetylation of the mixture which allowed separation and characterization of the acetylated products. Diacetate $\mathbf{1 1}$ could be isolated as individual compound to be well suited for our purposes.

Its oxidation with $\mathrm{CrO}_{3}$ in pyridine smoothly gave the expected 1-oxo-5 $\alpha$-alcohol 12 (Scheme 3). The general procedure for the radical oxidation of $\mathbf{1 2}$ was similar to that described in earlier papers. ${ }^{10,19}$ The reaction was carried out in refluxing benzene using a 1.5 mol excess of lead tetraacetate with the presence of iodine as a catalyst and calcium carbonate as a base. Although it resulted in the formation of a complex mixture of products, compound $\mathbf{1 3}$ could be isolated in a reasonable $56 \%$ yield.

11

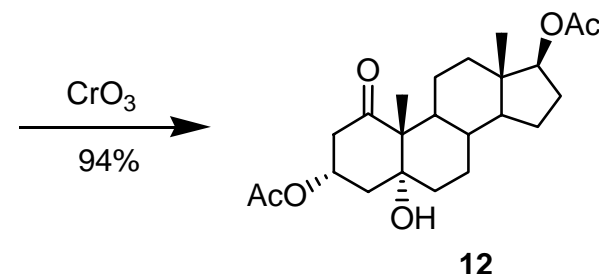

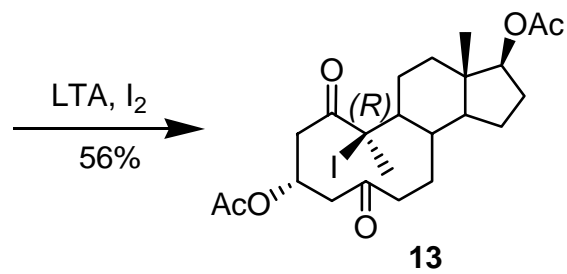

13

\section{Scheme 3}

It is noteworthy that the outcome of the reaction is strongly dependent on reaction conditions. Radical oxidation of similar 1-oxo-3 $\beta$-acetoxy steroids with lead tetraacetate under thermal or hypoiodite conditions or with mercuric oxide/iodine $\left(\mathrm{HgO} / \mathrm{I}_{2}\right)$ reagent was $\operatorname{shown}^{20}$ to give 1,5 dioxo-5,10-secocholest-10(19)-ene as a main product.

Although iodide 13 produced good crystals suitable for X-ray analysis, because of its photolability this method proved unsuitable for structure elucidation. Fortunately, the problem 
could be solved by a combination of NMR and CD spectroscopy. Full assignment of signals both in ${ }^{1} \mathrm{H}$ and ${ }^{13} \mathrm{C}$ spectra in 5,10-seco steroid 13 was based on the analysis of 2D NMR data. Some signals were partially superimposed in $\mathrm{CDCl}_{3}$, and similar spectra were obtained for $\mathbf{1 3}$ also in $\mathrm{C}_{6} \mathrm{D}_{6}$ (Table 1). Assignment of $\mathrm{C}-1$ and $\mathrm{C}-5$ carbonyl groups relied on analysis of $\mathrm{HMBC}$ spectrum, showing coupling of $\mathrm{C}-1$ and $\mathrm{H}-19, \mathrm{H}-2$, and H-9, on one hand, and C-5 and H-4 and H-6, on the other hand. Perhaps the most important argument in favor of (10R) stereochemistry for 13 was the nuclear Overhauser effect of C-19 methyl group and proton at C-8. There was also a cross-peak in the NOESY spectrum between signals of C-19 methyl group and $11 \beta$-proton.

Table 1. ${ }^{1} \mathrm{H}(500 \mathrm{MHz})$ and ${ }^{13} \mathrm{C}$ NMR $(125 \mathrm{MHz})$ data for $\mathbf{1 3}(\delta, J$ in $\mathrm{Hz})$

\begin{tabular}{|c|c|c|c|c|}
\hline $\mathrm{C} / \mathrm{H}$ & $\delta_{\mathrm{C}}, \mathrm{CDCl}_{3}$ & $\delta_{\mathrm{H}}, \mathrm{CDCl}_{3} *$ & $\delta_{\mathrm{C}}, \mathrm{C}_{6} \mathrm{D}_{6}$ & $\delta_{\mathrm{H}}, \mathrm{C}_{6} \mathrm{D}_{6}$ \\
\hline 1 & 204.82 & - & 204.95 & - \\
\hline 2 & 37.34 & $\begin{array}{l}4.22 \mathrm{dd}(6.1,17.9) \\
3.43 \mathrm{dd}(10.9,17.9)\end{array}$ & 38.19 & $\begin{array}{r}4.10 \mathrm{dd}(6.1,17.5) \\
3.19 \mathrm{dd}(10.6,17.5)\end{array}$ \\
\hline 3 & 67.84 & $5.60 \mathrm{~m}$ & 69.02 & $5.76 \mathrm{~m}$ \\
\hline 4 & 42.31 & $\begin{array}{l}3.10 \mathrm{dd}(3.2,14.7) \\
2.62 \mathrm{dd}(5.1,14.7)\end{array}$ & 42.85 & $\begin{array}{l}2.96 \mathrm{dd}(2.6,14.7) \\
2.72 \mathrm{dd}(5.8,14.7)\end{array}$ \\
\hline 5 & 208.91 & - & 207.67 & - \\
\hline 6 & 39.33 & $2.3,2 \mathrm{H}$ & 40.11 & $1.96 \mathrm{~m} 1.77 \mathrm{~m}$ \\
\hline 7 & $23.27 * *$ & $1.5,1.3$ & 23.63 & $0.94,2 \mathrm{H}$ \\
\hline 8 & 35.48 & 1.81 & 36.16 & $1.23 \mathrm{~m}$ \\
\hline 9 & 45.87 & 2.2 & 46.49 & $1.69 \mathrm{~m}$ \\
\hline 10 & 65.21 & - & 66.44 & - \\
\hline 11 & 31.92 & $2.49 \mathrm{~m}, 1.76$ & 32.62 & $2.29 \mathrm{~m}, 1.40$ \\
\hline 12 & 37.11 & $1.79,1.30$ & 37.72 & $1.60 \mathrm{~m}, 1.1 \mathrm{~m}$ \\
\hline 13 & 42.60 & - & 43.30 & - \\
\hline 14 & 46.30 & $1.20 \mathrm{~m}$ & 46.72 & $0.65 \mathrm{~m}$ \\
\hline 15 & $23.03 * *$ & $1.5,1.3$ & 23.50 & $0.99,0.79$ \\
\hline 16 & 27.66 & $2.2,1.54$ & 28.54 & $2.07 \mathrm{~m}, 1.39$ \\
\hline 17 & 81.54 & $4.60 \mathrm{dd}(8.3,8.3)$ & 82.14 & $4.66 \mathrm{~d}(8.7,8.7)$ \\
\hline 18 & 11.96 & $0.83 \mathrm{~s}$ & 12.26 & $0.58 \mathrm{~s}$ \\
\hline 19 & 24.45 & $2.07 \mathrm{~s}$ & 25.10 & $1.86 \mathrm{~s}$ \\
\hline 3-OAc & 169.77 & - & 169.72 & - \\
\hline 17-OAc & 171.04 & - & 170.72 & - \\
\hline 3-OAc & 21.07 & $2.04 \mathrm{~s}$ & 21.21 & 1.66 \\
\hline $17-\mathrm{OAc}$ & 21.11 & $2.05 \mathrm{~s}$ & 21.31 & 1.73 \\
\hline
\end{tabular}

* when multiplicities are not specified, the values of the ${ }^{1} \mathrm{H}$ chemical shifts are obtained from the HSQC spectrum.

** assignments may be reversed. 
NMR spectrum in $\mathrm{C}_{6} \mathrm{D}_{6}$ proved to be especially useful for analyzing the nuclear Overhauser effect, because in $\mathrm{CDCl}_{3}$ signal of $\mathrm{H}-8$ was partially superimposed on signals of other protons (H-11 and H-12). In $\mathrm{C}_{6} \mathrm{D}_{6}$ this proton could be observed as separate signal. Results of $\mathrm{CD}$ spectroscopy were in line with the proposed structure. CD spectrum of $\mathbf{1 3}$ showed a strong negative Cotton effect due to the $n-\pi^{*}$ transition at $313 \mathrm{~nm}$. A crucial input in the observed effect probably belongs to the iodine atom located at $\alpha$-position to $\mathrm{C}-1$ carbonyl group. The octant rule $^{21}$ for a model of $\mathbf{1 3}$ with a $\alpha$-orientation of iodine that provides a close relationship between C-19 methyl group and H-8 hydrogen atom shows that the iodine atom occupies the upper right rear octant for which the negative Cotton effect is predicted.

It should be noted that some intermediate compounds in the synthesis of iodide $\mathbf{1 3}$ contain a combination of structural elements characteristic of natural steroids. Withanolides and physalins have to be mentioned first. ${ }^{22}$ For instance, salpichrolide B isolated from from plant Salpichroa origanifolia has the same cycles $\mathrm{A}$ and $\mathrm{B}$ as epoxide $9 .^{23}$

In conclusion, the present study shows definite involvement of 1-keto group in the process of radical oxidation of $5 \alpha$-hydroxy steroids. The formed compounds are stable enough and can be used as intermediate products to prepare 5,10-seco steroids using approaches described previously. ${ }^{11}$

\section{Experimental Section}

General Procedures. Melting points were taken on a Boetius micro-melting point apparatus and are uncorrected. IR spectra were recorded on a UR-20 spectrophotometer in $\mathrm{KBr}$ tablets. CD spectra were taken on a JASCO J-20 spectropolarimeter. ${ }^{1} \mathrm{H}$ and ${ }^{13} \mathrm{C}$ NMR spectra were obtained using a Bruker AVANCE 500 (Bruker Biospin) spectrometer in $\mathrm{CDCl}_{3}$ (if not stated otherwise) operating at $500 \mathrm{MHz}$ for ${ }^{1} \mathrm{H}$ and $125 \mathrm{MHz}$ for ${ }^{13} \mathrm{C}$. Chemical shifts were determined relative to the residual solvent peaks $\left(\mathrm{CHCl}_{3}, \delta=7.26\right.$ for hydrogen atoms, $\delta=77$ for carbon atoms). Full assignment of ${ }^{1} \mathrm{H}$ and ${ }^{13} \mathrm{C}$ chemical shifts of 5,10-seco steroid 13 (Table 1) was achieved with the aid of COSY, HSQC, HMBC, J-resolved, TOCSY, NOESY experiments using the standard Bruker pulse programs. The exact mass measurements were carried out on a Micromass MasSpec mass spectrometer operating in the $70 \mathrm{eV}$-EI mode. A direct insertion probe was used to introduce samples for accurate mass measurement by peak matching. All chemicals were of analytical grade. Reactions were monitored by TLC using aluminium or plastic sheets, silica gel $60 \mathrm{~F}_{254}$ precoated (Merck Art. 5715). Column chromatography was carried out on silica gel 60 (Merck Art. 7734).

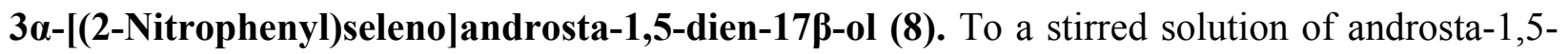

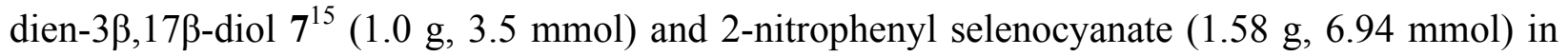
$40 \mathrm{~mL}$ of dry THF, tributylphosphine $(85 \%, 2.0 \mathrm{~mL}, 6.94 \mathrm{mmol})$ was added dropwise under argon. The reaction mixture was stirred for $48 \mathrm{~h}$ at room temperature, and then solvents were 
evaporated under reduced pressure. The residue was purified by column chromatography (toluene - EtOAc, 6:1) to give the title compound $8(1.48 \mathrm{~g}, 90 \%)$ as an oil. ${ }^{1} \mathrm{H}$ NMR $\delta 0.79(3 \mathrm{H}$, s, 18- $\left.\mathrm{CH}_{3}\right), 1.10\left(3 \mathrm{H}, \mathrm{s}, 19-\mathrm{CH}_{3}\right), 2.40(\mathrm{~m}, 1 \mathrm{H}), 3.09\left(1 \mathrm{H}, \mathrm{m}, \mathrm{C}_{3}-\mathrm{H}\right), 3.67(1 \mathrm{H}, \mathrm{dd}, J=8.5,8.5$ $\left.\mathrm{Hz}, \mathrm{C}_{17}-\mathrm{H}\right), 4.18(1 \mathrm{H}, \mathrm{t}, J=4.9 \mathrm{~Hz}), 5.39\left(1 \mathrm{H}, \mathrm{m}, \mathrm{C}_{6}-\mathrm{H}\right), 5.81\left(1 \mathrm{H}, \mathrm{m}, \mathrm{C}_{2}-\mathrm{H}\right), 5.94(1 \mathrm{H}, \mathrm{d}, J=9.8$ $\left.\mathrm{Hz}, \mathrm{C}_{1}-\mathrm{H}\right), 7.30(1 \mathrm{H}$, ddd, $J=1.1,7.2,8.3 \mathrm{~Hz}$, arom. H), $7.52(1 \mathrm{H}$, ddd, $J=1.4,7.3,8.3 \mathrm{~Hz}$, arom. H), $7.62\left(1 \mathrm{H}, \mathrm{d}, J=7.7 \mathrm{~Hz}\right.$, arom. H), $8.25(1 \mathrm{H}, \mathrm{dd}, J=1.3,8.3 \mathrm{~Hz}$, arom. $\mathrm{H}) ;{ }^{13} \mathrm{C} \mathrm{NMR} \delta$ 11.0, 20.6, 21.8, 23.4, 30.4, 30.7, 31.9, 35.8, 36.4, 38.8, 40.5, 42.7, 46.6, 51.3, 81.7, 123.3, 123.4, $125.3,126.4,129.5,133.5,136.9,139.0$.

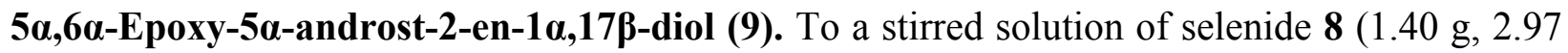
$\mathrm{mmol})$ in $30 \mathrm{~mL}$ of THF, $\mathrm{H}_{2} \mathrm{O}_{2}(30 \%, 8.7 \mathrm{~mL}, 77 \mathrm{mmol})$ was added at $-30^{\circ} \mathrm{C}$. The reaction mixture was stirred at this temperature for $1 \mathrm{~h}$, and then $5 \mathrm{~mL}$ of pyridine was added. The cooling bath was removed and the mixture was stirred at ambient temperature for $18 \mathrm{~h}$. Then it was diluted with water and extracted with EtOAc $(3 \times 100 \mathrm{~mL})$. The combined organic extracts were washed with saturated $\mathrm{NaHCO}_{3}$, water, dried over $\mathrm{Na}_{2} \mathrm{SO}_{4}$ and evaporated under reduced pressure. The residue was chromatographed on $\mathrm{SiO}_{2}$ (cyclohexane $\left.-\mathrm{EtOAc}=6: 1=>2: 1\right)$ to afford $0.32 \mathrm{~g} \mathrm{(35 \% )}$ of monoepoxide 9 as white crystals, $\mathrm{mp} 65-67^{\circ} \mathrm{C}$ (hexane - EtOAc) (Found: $\mathrm{M}^{+}$; 304.2038. $\mathrm{C}_{19} \mathrm{H}_{28} \mathrm{O}_{3}$ requires $\mathrm{M}^{+}$; 304.2038). MS (EI) $\mathrm{m} / \mathrm{z}(\%) 304\left(\mathrm{M}^{+}\right.$; 48), $286(100), 271$ (20), 261 (22), 257 (47), 248 (44), 235 (100). ${ }^{1} \mathrm{H}$ NMR $\delta 0.71\left(3 \mathrm{H}, \mathrm{s}, 18-\mathrm{CH}_{3}\right), 1.04$ (3H, s, 19$\left.\mathrm{CH}_{3}\right), 3.63\left(1 \mathrm{H}, \mathrm{dd}, J=8.6,8.6 \mathrm{~Hz}, \mathrm{C}_{17}-\mathrm{H}\right), 3.82\left(1 \mathrm{H}, \mathrm{dd}, J=5.2,8.9 \mathrm{~Hz}, \mathrm{C}_{1}-\mathrm{H}\right), 5.76(1 \mathrm{H}, \mathrm{m}$, $\left.\mathrm{C}_{2}-\mathrm{H}\right), 6.00\left(1 \mathrm{H}, \mathrm{m}, \mathrm{C}_{3}-\mathrm{H}\right) ;{ }^{13} \mathrm{C} \mathrm{NMR} \delta 10.9,15.5,19.6,23.3,29.0,30.19,30.19,32.7,36.0$, $36.5,38.9,42.6,51.6,55.7,62.5,70.8,81.6,125.7,129.0$.

$\mathbf{2 \alpha , 3 \alpha ; 5 \alpha , 6 \alpha - D i e p o x y - 5 \alpha - a n d r o s t a n - 1 7 \beta - o l ~ ( 1 0 ) . ~ T o ~ a ~ s t i r r e d ~ s o l u t i o n ~ o f ~ m o n o e p o x i d e ~} 9$ (330 $\mathrm{mg}, 1.09 \mathrm{mmol})$ in $15 \mathrm{~mL}$ of dry $\mathrm{CH}_{2} \mathrm{Cl}_{2}$, MCPBA (77\%, $\left.486 \mathrm{mg}, 2.18 \mathrm{mmol}\right)$ was added. The reaction mixture was stirred for $20 \mathrm{~h}$ at room temperature. Then it was diluted with $200 \mathrm{~mL}$ of $\mathrm{CH}_{2} \mathrm{Cl}_{2}$ and washed consecutively with $5 \% \mathrm{NH}_{4} \mathrm{OH}$ and water. The organic phase was evaporated to dryness. The residue was chromatographed on $\mathrm{SiO}_{2}$ (cyclohexane - EtOAc $\mathrm{MeOH}=1: 1.5: 0.07)$ to give $285 \mathrm{mg}(82 \%)$ of diepoxide $\mathbf{1 0}$ as white crystals, $\mathrm{mp} 161-165^{\circ} \mathrm{C}$ (hexane - EtOAc) (Found: $\mathrm{M}^{+} \cdot$, 320.1993. $\mathrm{C}_{19} \mathrm{H}_{28} \mathrm{O}_{4}$ requires $\mathrm{M}^{+}$; 320.1988). MS (EI) m/z (\%) $320\left(\mathrm{M}^{+}\right.$; 14), 302 (45), 284 (9), 273 (11), 259 (18), 248 (100), 235 (48). ${ }^{1} \mathrm{H}$ NMR $\delta 0.67$ (3H, s, $\left.18-\mathrm{CH}_{3}\right), 0.96\left(3 \mathrm{H}, \mathrm{s}, 19-\mathrm{CH}_{3}\right), 3.47(1 \mathrm{H}, \mathrm{m}), 3.52(1 \mathrm{H}, \mathrm{dd}, J=3.8,5.4 \mathrm{~Hz}), 3.60(1 \mathrm{H}, \mathrm{dd}, J=$ 8.6, 8.6 Hz, $\left.\mathrm{C}_{17}-\mathrm{H}\right), 3.82(\mathrm{~d}, 1 \mathrm{H}, J=5.5 \mathrm{~Hz}) ;{ }^{13} \mathrm{C} \mathrm{NMR} \delta 10.8,15.6,19.6,23.3,28.5,30.1,30.2$, 31.0, 35.9, 36.0, 38.1, 42.5, 51.4, 52.8, 53.3, 54.3, 59.5, 69.1, 81.4.

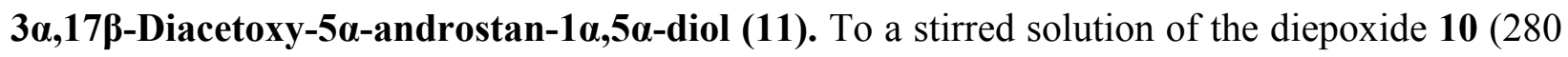
$\mathrm{mg}, 0.88 \mathrm{mmol})$ in $40 \mathrm{~mL}$ of $\mathrm{Et}_{2} \mathrm{O}, \mathrm{LiAlH}_{4}(401 \mathrm{mg}, 10.56 \mathrm{mmol})$ was added. The reaction mixture was stirred for $3 \mathrm{~h}$ at room temperature. Then water $(0.4 \mathrm{~mL}), 15 \% \mathrm{NaOH}(0.4 \mathrm{~mL})$, and again water $(1.2 \mathrm{~mL})$ was added consecutively. The resulting suspension was filtered and washed with $\mathrm{Et}_{2} \mathrm{O}(50 \mathrm{~mL})$. The filtrate was then evaporated to a syrupy consistence, re-dissolved in toluene $(20 \mathrm{~mL})$ and evaporated again. The obtained product $(260 \mathrm{mg})$ was used in the next step directly. It was dissolved in $4 \mathrm{~mL}$ of pyridine and $2 \mathrm{~mL}$ of $\mathrm{Ac}_{2} \mathrm{O}$ was added. The mixture was kept at room temperature for $20 \mathrm{~h}$. Solvents were partly evaporated under reduced pressure, then 
water was added and the mixture was extracted with EtOAc. The extracts were dried over $\mathrm{Na}_{2} \mathrm{SO}_{4}$ and evaporated. The residue was chromatograped on $\mathrm{SiO}_{2}$ (cyclohexane-EtOAc $=2: 1=>$ $1: 1)$ to give diacetate $11(136 \mathrm{mg}, 38 \%)$ as white crystals, mp $132-135^{\circ} \mathrm{C}$ (hexane-EtOAc). ${ }^{1} \mathrm{H}$ NMR $\delta 0.79\left(3 \mathrm{H}, \mathrm{s}, 18-\mathrm{CH}_{3}\right), 0.88\left(3 \mathrm{H}, \mathrm{s}, 19-\mathrm{CH}_{3}\right), 2.037(3 \mathrm{H}, \mathrm{s}, \mathrm{OAc}), 2.043(3 \mathrm{H}, \mathrm{s}, \mathrm{OAc}), 3.07$ $\left(1 \mathrm{H}\right.$, brs, $\left.\mathrm{C}_{5}-\mathrm{OH}\right), 3.79\left(\mathrm{~m}, 1 \mathrm{H}, \mathrm{C}_{1}-\mathrm{H}\right), 4.59\left(\mathrm{dd}, 1 \mathrm{H}, J=8.0,8.9 \mathrm{~Hz}, \mathrm{C}_{17}-\mathrm{H}\right), 5.18\left(1 \mathrm{H}, \mathrm{m}, \mathrm{C}_{3}-\mathrm{H}\right)$; ${ }^{13} \mathrm{C}$ NMR $\delta 12.2,16.7,20.0,21.2,21.6,23.4,25.1,27.5,33.0,34.6,34.7,36.7,38.3,40.2,41.9$, $42.7,50.4,68.7,72.0,74.4,82.8,170.2,171.2$; IR $v_{\max }(\mathrm{KBr}) 3060,2940,1730,1380,1255$, 1060 .

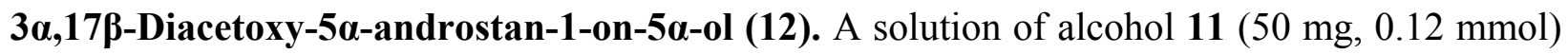
in $2 \mathrm{~mL}$ of pyridine was added to a suspension of $\mathrm{CrO}_{3}(120 \mathrm{mg}, 1.20 \mathrm{mmol})$ in $2 \mathrm{~mL}$ of pyridine at $0^{\circ} \mathrm{C}$. The reaction mixture was stirred at room temperature for $20 \mathrm{~h}$, then $0.5 \mathrm{~mL}$ of ${ }^{\mathrm{i}} \mathrm{PrOH}$ was added and stirring was continued for $30 \mathrm{~min}$. The mixture was diluted with $\mathrm{Et}_{2} \mathrm{O}$ and the resulting residue was passed through a short pad of $\mathrm{SiO}_{2}$. The residue after evaporation of the solvents was chromatograped on $\mathrm{SiO}_{2}$ to afford ketol 12 (47 mg, 94\%) as white crystals, mp 165$168^{\circ} \mathrm{C}$ (hexane-EtOAc) (Found: $\mathrm{M}^{+} \cdot$, 406.2352. $\mathrm{C}_{23} \mathrm{H}_{34} \mathrm{O}_{6}$ requires $\mathrm{M}^{+}$; 406.2355). $\mathrm{MS}$ (EI) $\mathrm{m} / \mathrm{z}$ (\%) $406\left(\mathrm{M}^{+}\right.$; 100), 346 (80), 328 (16), 305 (16), 286 (56), 271 (17). ${ }^{1} \mathrm{H}$ NMR $\delta 0.79$ (3H, s, 18$\left.\mathrm{CH}_{3}\right), 1.27\left(3 \mathrm{H}, \mathrm{s}, 19-\mathrm{CH}_{3}\right), 2.03(3 \mathrm{H}, \mathrm{s}, \mathrm{OAc}), 2.04(3 \mathrm{H}, \mathrm{s}, \mathrm{OAc}), 3.06(1 \mathrm{H}, \mathrm{dd}, J=5.5,14.9 \mathrm{~Hz}$, $\left.\mathrm{C}_{2}-\mathrm{H}\right), 4.58\left(1 \mathrm{H}, \mathrm{dd}, J=8.0,8.8 \mathrm{~Hz}, \mathrm{C}_{17}-\mathrm{H}\right), 5.51\left(1 \mathrm{H}, \mathrm{m}, \mathrm{C}_{3}-\mathrm{H}\right) ;{ }^{13} \mathrm{C}$ NMR $\delta 12.4,16.4,21.1$, $21.3,22.1,23.4,24.1,27.5,33.3,34.8,36.8,37.6,40.7,42.4,42.8,50.2$, 55.7, 72.2, 78.8, 82.9, $169.2,171.2,210.6$.

(10R)-3 $\alpha, 17 \beta$-Diacetatoxy-10-iodo-5,10-secoandrostan-1,5-dione (13). To a magnetically stirred suspension of ketol 12 (40 mg, $0.10 \mathrm{mmol}), \mathrm{Pb}(\mathrm{OAc})_{4}(66 \mathrm{mg}, 0.15 \mathrm{mmol})$, and $\mathrm{CaCO}_{3}$ (15 mg, $0.15 \mathrm{mmol})$ in $15 \mathrm{~mL}$ of benzene, iodine (19 $\mathrm{mg}, 0.15 \mathrm{mmol}$ ) was added after the mixture was heated to reflux. The stirring and refluxing were continued for $15 \mathrm{~min}$, then the mixture was cooled to room temperature and the precipitate was filtered off. The filtrate was washed with saturated $\mathrm{Na}_{2} \mathrm{~S}_{2} \mathrm{O}_{3}$, water, dried over $\mathrm{Na}_{2} \mathrm{SO}_{4}$ and evaporated. The residue was chromatograped on $\mathrm{SiO}_{2}$ (cyclohexane-EtOAc = 3:1) to give iodide $13(30 \mathrm{mg}, 58 \%$ ) as white crystals, mp $130-132^{\circ} \mathrm{C}$. (Found: $\mathrm{M}^{+}$; 532.1310. $\mathrm{C}_{23} \mathrm{H}_{33} \mathrm{IO}_{6}$ requires $\mathrm{M}^{+}$; 532.1322). $\mathrm{MS}(\mathrm{EI}) \mathrm{m} / \mathrm{z}$ (\%) $532\left(\mathrm{M}^{+}\right.$; 16), 472 (8), 406 (100), 346 (75), 328 (19), 286 (48), 254 (50). CD (methanol) $\lambda$ $\left([\theta]_{\mathrm{M}}\right) 313(-20,000), 217(-5,300), 206(11,000)$.

\section{Acknowledgements}

We thank Sybille Lorenz (Jena) for the high resolution mass measurements and Emily Wheeler (Jena) for linguistic support in the preparation of this manuscript. 


\section{References}

1. Mez, H.-C.; Rist, G.; Kalvoda, J.; Ermer, O.; Lorenc, L.; Mihailović, M. L. Helv. Chim. Acta 1976, 59, 1273.

2. Fuhrer, H.; Lorenc, L.; Pavlović, V.; Rihs, G.; Rist, G.; Kalvoda, J.; Mihailovic, M. L. Helv. Chim. Acta 1981, 64, 703.

3. Mihailović, M. L.; Lorenc, L.; Gai, M.; Rogi, M.; Melera, A.; Stefanović, M. Tetrahedron 1966, 22, 2345.

4. Lorenc, L.; Rajković, M.; Milovanović, A.; Mihailović, M. L. J. Chem. Soc., Perkin Trans. 1 1988, 1495.

5. Lorenc, L.; Pavlović, V.; Mihailović, M. L.; Kalvoda, J.; Fuhrer, H. Helv. Chim. Acta 1991, $74,1459$.

6. Lorenc, L. B.; Pavlovic, V. D.; Mihailovic, M. L.; Krsti, N. M. Helv. Chim. Acta 1993, 76, 2254.

7. Heckendorn, R.; Führer, H.; Kalvoda, J.; Lorenc, L.; Pavlović, V.; Mihailović, M. L. Helv. Chim. Acta 1995, 78, 1291.

8. Khripach, V. A.; Zhabinskii, V. N.; Kuchto, A. I.; Zhiburtovich, Y. Y.; Gromak, V. V.; Groen, M. B.; van der Louw, J.; de Groot, A. Tetrahedron Lett. 2006, 47, 6715.

9. Bjelaković, M. C.; Lorenc, L. B.; Pavlović, V. D.; Mihailović, M. L.; Tinant, B.; Declercq, J. P.; Kalvoda, J. Helv. Chim. Acta 1999, 82, 707.

10. Khripach, V. A.; Zhabinskii, V. N.; Kotyatkina, A. I.; Fando, G. P.; Zhiburtovich, Y. Y.; Lyakhov, A. S.; Govorova, A. A.; Groen, M.; van der Louw, J.; de Groot, A. Collect. Czech. Chem. Commun. 2001, 66, 1764.

11. Khripach, V. A.; Zhabinskii, V. N.; Kuchto, A. I.; Zhiburtovich, Y. Y.; Fando, G. P.; Lyakhov, A. S.; Govorova, A. A.; Groen, M.; van der Louw, J.; de Groot, A. Steroids 2004, 69, 501.

12. Khripach, V. A.; Zhabinskii, V. N.; Kuchto, A. I.; Fando, G. P.; Zhiburtovich, Y. Y.; Lyakhov, A. S.; Govorova, A. A.; Groen, M.; van der Louw, J.; de Groot, A. Steroids 2004, 69, 511.

13. Zhu, G.-D.; Okamura, W. H. Chem. Rev. 1995, 95, 1877.

14. Zhabinskii, V. N.; Minnaard, A. J.; Wijnberg, J. B. P. A.; de Groot, A. J. Org. Chem., 1996, 61, 4022.

15. Shapiro, E.; Weber, L.; Oliveto, E. P.; Herzog, H. L.; Neri, R.; Tolksdorf, S.; Tanabe, M.; Crowe, D. F. Steroids 1966, 8, 461.

16. Grieco, P. A.; Gilman, S.; Nishizawa, M. J. Org. Chem. 1976, 41, 1485.

17. Zoretic, P. A.; Chambers, R. J.; Marbury, G.; Riebiro, A. A. J. Org. Chem. 1985, 50, 2981.

18. Grieco, P. A.; Yokoyama, Y.; Gilman, S.; Nishizawa, M. J. Org. Chem. 1977, 42, 2034.

19. Khripach, V. A.; Zhabinskii, V. N.; Kuchto, A. I.; Zhiburtovich, Y. Y.; Lyakhov, A. S.; Govorova, A. A.; Groen, M.; van der Louw, J.; de Groot, A. Steroids 2006, 71, 504-509. 
20. Krstić, N. M.; Bjelaković, M. S.; Lorenc, L. B.; Pavlović, V. D. J. Serb. Chem. Soc. 2003, $68,785$.

21. Eliel, E. L.; Wilen, S. H.; Mander, L. N. Stereochemistry of Organic Compounds; John Wiley \& Sons: New York, 1993.

22. Glotter, E. Nat. Prod. Rep. 1991, 8, 415.

23. Veleiro, A. S.; Burton, G.; Bonetto, G. M.; Gil, R. R.; Oberti, J. C. J. Nat. Prod. 1994, 57, 1741 . 